\title{
Microbial contamination of contact lens storage cases during daily wear use
}

DOI:

10.1097/OPX.0000000000000886

\section{Document Version}

Accepted author manuscript

Link to publication record in Manchester Research Explorer

\section{Citation for published version (APA):}

Dantam, J., McCanna, D. J., Subbaraman, L. N., Papinski, D., Lakkis, C., Mirza, A., Berntsen, D. A., Morgan, P., Nichols, J. J., Jones, L. W., Mathew, J. H., Cox, S. M., Bickle, K. M., Powell, D. R., Cox, J., Miller, W. L., WallaceTucker, A., Charrier, S., Chen, Y. J., ... Lada, M. W. (2016). Microbial contamination of contact lens storage cases during daily wear use. Optometry and Vision Science, 93(8), 925-932.

https://doi.org/10.1097/OPX.0000000000000886

\section{Published in:}

Optometry and Vision Science

\section{Citing this paper}

Please note that where the full-text provided on Manchester Research Explorer is the Author Accepted Manuscript or Proof version this may differ from the final Published version. If citing, it is advised that you check and use the publisher's definitive version.

\section{General rights}

Copyright and moral rights for the publications made accessible in the Research Explorer are retained by the authors and/or other copyright owners and it is a condition of accessing publications that users recognise and abide by the legal requirements associated with these rights.

\section{Takedown policy}

If you believe that this document breaches copyright please refer to the University of Manchester's Takedown Procedures [http://man.ac.uk/04Y6Bo] or contact uml.scholarlycommunications@manchester.ac.uk providing relevant details, so we can investigate your claim.

\section{OPEN ACCESS}




\title{
Optometry and Vision Science \\ Microbial Contamination of Contact Lens Storage Cases During Daily Wear Use \\ --Manuscript Draft--
}

Manuscript Number:

Full Title:

Article Type:

Keywords:

Corresponding Author:
OVS15496R2

Microbial Contamination of Contact Lens Storage Cases During Daily Wear Use

Original Article

contact lens, storage case, solution, contamination, biofilm, bacteria

Jaya Dantam, PhD, BOptom

University of Waterloo

Waterloo, ON - Ontario CANADA

Corresponding Author Secondary Information:

Corresponding Author's Institution:

University of Waterloo

Corresponding Author's Secondary Institution:

First Author:

Jaya Dantam, PhD, BOptom

First Author Secondary Information:

Order of Authors:

\author{
Jaya Dantam, PhD, BOptom \\ David Joseph McCanna, PhD \\ Lakshman Nagapatnam Subbaraman, PhD, BSOptom \\ Dominik Papinski, PhD \\ Carol Lakkis, PhD, PGCertOcTher, FAAO, FACO, FBCLA \\ Aftab Mirza, MSc, MCOptom \\ David A Berntsen, OD, PhD, FAAO \\ Philip Morgan, PhD, MCOptom, FAAO, FBCLA \\ Jason J Nichols, OD, MPH, PhD, FAAO \\ Lyndon Jones, PhD, FCOptom, FAAO
}

Order of Authors Secondary Information:

\begin{tabular}{|c|c|}
\hline Abstract: & $\begin{array}{l}\text { Purpose: To evaluate contact lens }(C L) \text { storage case contamination when used with } \\
\text { four different CL care solutions, during daily wear of three different CL materials. } \\
\text { Methods: A parallel, prospective, bilateral, randomized clinical trial ( } n=38 \text { ) was } \\
\text { conducted. Subjects were randomly assigned to use one of three CL materials } \\
\text { (etafilcon A, senofilcon A or galyfilcon A) on a daily wear basis. Subsequently, each } \\
\text { subject randomly used one of four different CL care solutions (Biotrue, OPTI-FREE } \\
\text { PureMoist, RevitaLens OcuTec and CLEAR CARE) for two weeks, along with their } \\
\text { respective storage cases. After every two-week period, their storage cases were } \\
\text { collected and the right and left wells of each storage case were randomized for two } \\
\text { procedures: (i) microbial enumeration by swabbing the storage case surface and (ii) } \\
\text { evaluation of biofilm formation (multipurpose solution cases only) using a crystal violet } \\
\text { staining assay. } \\
\text { Results: More than } 80 \% \text { of storage cases were contaminated when used in conjunction } \\
\text { with the four CL care solutions, irrespective of the CL material worn. Storage cases } \\
\text { maintained with CLEAR CARE (mean Log colony forming units }(C F U) / \text { well } \pm \text { SD, } 2.0 \pm \\
1.0) \text { revealed significantly ( } p<0.001) \text { greater levels of contamination, compared to } \\
\text { those maintained with Biotrue }(1.3 \pm 0.8) \text { and RevitaLens OcuTec }(1.2 \pm 0.8) \text {. } \\
\text { Predominantly, storage cases were contaminated with Gram-positive bacteria ( } \geq 80 \%) \text {. } \\
\text { There were significant differences ( } p=0.013 \text { ) for the levels of Gram-negative bacteria }\end{array}$ \\
\hline
\end{tabular}


recovered from the storage cases maintained with different $C L$ care solutions. Storage cases maintained with OPTI-FREE PureMoist $(0.526 \pm 0.629)$ showed significantly higher biofilm formation $(p=0.028)$ compared to those maintained with Biotrue $(0.263 \pm$ 0.197).

Conclusions: Levels of contamination ranged from 0 to $6.4 \mathrm{Log}$ CFU/storage case well, which varied significantly $(p<0.001)$ between different $C L$ care solutions and storage case contamination was not modulated by $\mathrm{CL}$ materials. 


\section{Synopsis for "Microbial contamination of contact lens storage cases during daily wear use"}

This study evaluated the frequency and levels of microbial contamination in contact lens $(C L)$ storage cases, during the daily wear of three different CL materials that were used in combination with three contemporary CL care solutions with dual disinfectants and a hydrogen-peroxide based solution. Overall, at least $80 \%$ of storage cases were contaminated. The levels of storage case contamination varied significantly between different $C L$ care solutions and was not modulated by $C L$ materials. It is worthwhile, to evaluate the association between microbial contamination and the occurrence of adverse events during CL wear in a future study.

Short title for OVS announces: Microbial contamination of contact lens storage cases 


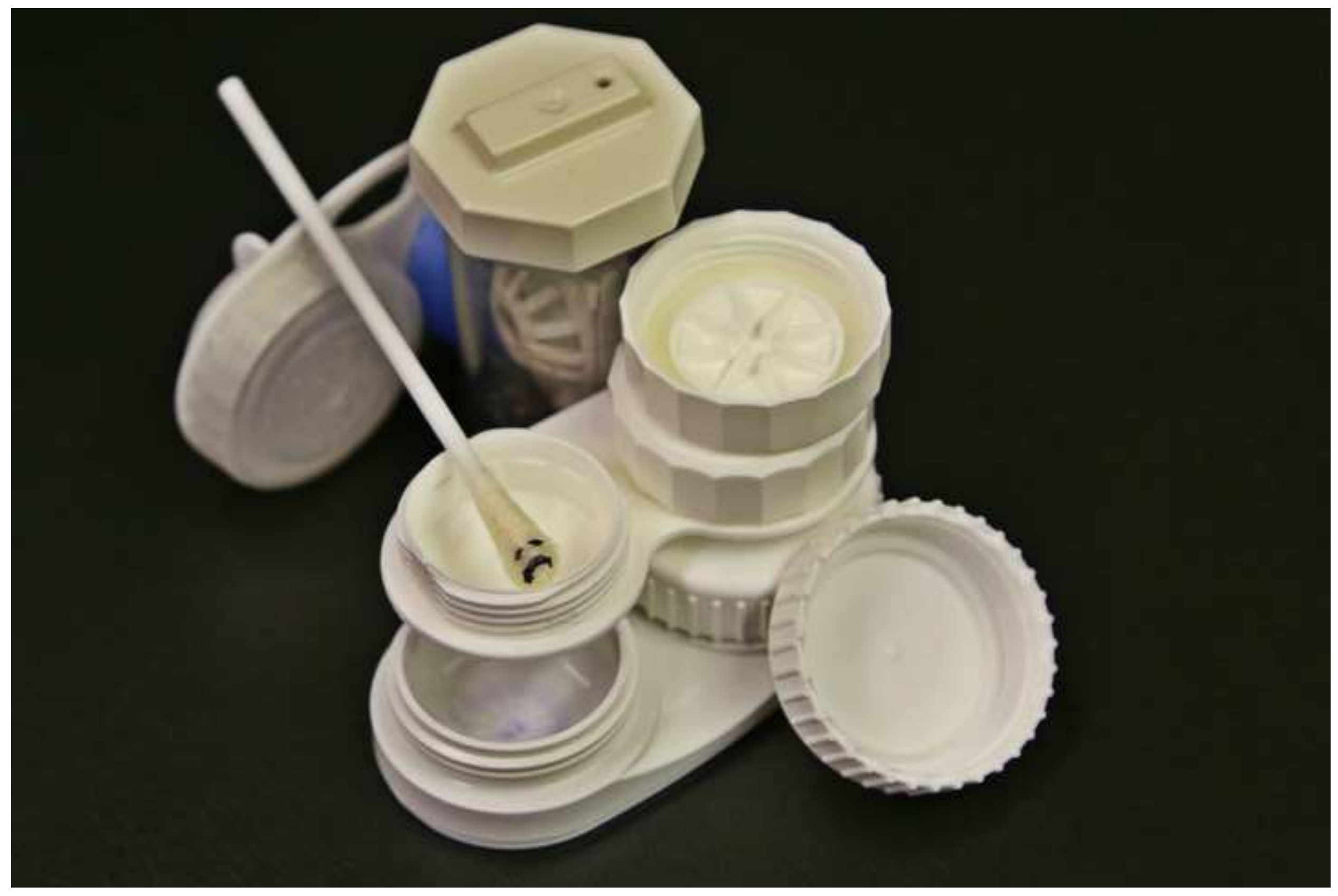




\section{Ref.: Ms. No. OVS15496R1- "Microbial Contamination of Contact Lens Storage Cases During Daily Wear Use"}

\section{Dear Dr Twa,}

Many thanks for providing comments on our revised manuscript. Kindly, please find our responses (text in red) to the editors' comments below.

Best regards,

Jaya

Jaya Dantam PhD, B.Optom

Laboratory Scientist

Centre for Contact Lens Research | School of Optometry \& Vision Science

University of Waterloo 200 University Ave West, Waterloo, Ontario, N2L 3G1 | Canada

Tel: 519-888-4567 x36590 | Fax: 519-888-4303 | $\underline{\text { cclr.uwaterloo.ca }}$

(CLR WNIVERSIYO OOF

This email and any attachments are confidential. If you are not an intended recipient or an authorised representative of an intended recipient, please notify the sender immediately by return email and delete all copies of this email and any attachments. 


\section{Editor in Chief's comments:}

Jaya, the revisions have improved this manuscript. Thank you.

Thank you.

There are a few outstanding point to address:

While reasonable, the journal generally does not add or subtract authors form those listed originally without ample justification and clear consent of others involved.

This is an author not a journal responsibility to address. If you wish to change the author list, you must provide written consent from all other authors before we will even consider such a request. This must include a statement that they specifically agree to adding this specific individual, that the proposed new author meets the ICMJE author criteria, and that the position in the list is acceptable to all:

(http://www.icmje.org/recommendations/browse/roles-and-responsibilities/defining-the-role-ofauthors-and-contributors.html).

Yes, as per your suggestion, we have obtained the written consent from all the co-authors (enclosed), for your consideration, to add Dominik as a co-author.

Please follow the Managing Editor's instructions below regarding your OVS Announces synopsis image and image licensing agreement form.

Yes, sure.

\section{Topical Editor's comments:}

The manuscript has been appropriately revised based on the reviewers comments.

Some additional comments below:

line 121 "The storage cases maintained with OPTI-FREE PureMoist $(0.3 \pm 0.9)$ showed" what are the numbers? cfu? or? please clarify. similarly at line 125 "OcuTec $(0.1 \pm 0.3)$ were not significantly different" what are these numbers?

Apologies for not clarifying the units earlier. These numbers refer to mean Log CFU/ storage case well \pm SD. As per your suggestion, we have now added these units beside the numbers (please refer to lines 121, 122 and 125).

Again - lines 160-160 - what are the numbers? Log cfu?

As above, these numbers refer to mean Log CFU/ storage case well $\pm \mathrm{SD}$. We have now added the units in lines 160 and 161.

Abstract - add key words at the end of the abstract text file.

We have now added the key words at the end of the abstract.

Acknowledgments - I don't understand why the houston, Manchester sites are acknowledged - 
the data did not come from these sites - I would suggest removing all of the "site" acknowledgments"

We agree that the data was not collected or analyzed at the Manchester and Houston sites. However, as this study was part of the main multi-site study (assessing the clinical performance of contemporary care systems), we have included these sites in the acknowledgement section.

On this topic - was there a significant contribution from; listed authors other than those at the Canada site and sponsor to warrant an authorship? Even the stats seems to have been performed in Canada with help from Canadian (German) person.

Please note that the contributions from each author listed in this manuscript have been identified as per ICMJE criteria and we have enclosed these declaration forms for your reference.

Table 3 - column 2 - I presume this is $\log 10 \mathrm{CFU} / \mathrm{ml}$ ? Needs to have this added above (mean +/$\mathrm{SD})$.

Yes, as per your suggestion we have now added the units in Table 3.

Managing Editor's instructions regarding your OVS Announces image and licensing agreement form:

Please upload an interesting/compelling color image of a topic loosely related to your study as the "OVS Announces synopsis image" (choose "Synopsis of manuscript" as the "File type"). Examples of previously published OVS Announces images can be found at http://journals.lww.com/optvissci/pages/collectiondetails.aspx?TopicalCollectionId=6.

The image must be a color, high-resolution (350ppi) TIFF or JPG file that is 3 " wide by 2 " tall.

DO NOT submit a file acquired from an outside source (the internet, another published work, etc.). The creator of the image MUST also complete and sign a "Licensing Agreement" form which grants OVS the right to publish the image. Upload the signed, filled out form as an "Author Agreement" file with your revision. The licensing agreement form is available athttp://edmgr.ovid.com/ovs/accounts/OVS_Announces_License_Form.pdf.

Yes we have uploaded a synopsis image. 


\section{Declaration for the addition of a co-author}

I, Jaya Dantam (print first, middle, last name) agree to the addition of Dr Dominik Papinski as a co-author in our manuscript entitled "Microbial contamination of contact lens storage cases during daily wear use" (manuscript number: OVS15496R1) in recognition of his significant contributions to the statistical analysis (as per the stated authors list below).

I also agree that he meets the ICMJE (http://www.icmje.org/recommendations/browse/roles-andresponsibilities/defining-the-role-of-authors-and-contributors.html) author criteria.

Jaya Dantam* PhD, BOptom; David J McCanna* PhD; Lakshman N Subbaraman* PhD, BSOptom; Dominik Papinski* PhD; Carol Lakkis ${ }^{\dagger}$ PhD, PGCertOcTher, FAAO; Aftab Mirza ${ }^{\#}$ MSc, MCOptom; David A Berntsen $\$$, PhD, OD, FAAO; Philip Morgan ${ }^{\sharp} \mathrm{PhD}$, MCOptom, FAAO; Jason J Nichols ${ }^{\ddagger} \mathrm{PhD}$, M.P.H, FAAO; Lyndon Jones* PhD, FCOptom, FAAO; for the Performance of Contact Lens Solutions Study Group

* Centre for Contact Lens Research, School of Optometry \& Vision Science, University of Waterloo, Canada, ${ }^{\dagger}$ Johnson \& Johnson Vision Care, USA, " Eurolens Research, University of Manchester, UK, ${ }^{5}$ The Ocular Surface Institute, College of Optometry, University of Houston, Houston, TX, USA, ${ }^{\ddagger}$ School of Optometry, University of Alabama at Birmingham, Birmingham, AL, USA

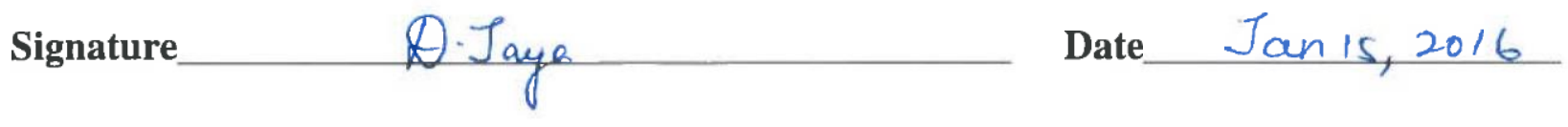




\section{Declaration for the addition of a co-author}

I, Dav.d Joseph MC Canna (print first, middle, last name) agree to the addition of Dr Dominik Papinski as a co-author in our manuscript entitled "Microbial contamination of contact lens storage cases during daily wear use" (manuscript number: OVS15496R1) in recognition of his significant contributions to the statistical analysis (as per the stated authors list below).

I also agree that he meets the ICMJE (http://www.icmje.org/recommendations/browse/roles-andresponsibilities/defining-the-role-of-authors-and-contributors.html) author criteria.

Jaya Dantam* PhD, BOptom; David J McCanna* PhD; Lakshman N Subbaraman* PhD, BSOptom; Dominik Papinski* PhD; Carol Lakkis ${ }^{\dagger}$ PhD, PGCertOcTher, FAAO; Aftab Mirza ${ }^{\#}$ MSc, MCOptom; David A Berntsen ${ }^{\S}$ PhD, OD, FAAO; Philip Morgan ${ }^{\#} \mathrm{PhD}$, MCOptom, FAAO; Jason J Nichols ${ }^{\ddagger} \mathrm{PhD}$, M.P.H, FAAO; Lyndon Jones* PhD, FCOptom, FAAO; for the Performance of Contact Lens Solutions Study Group

* Centre for Contact Lens Research, School of Optometry \& Vision Science, University of Waterloo, Canada, ${ }^{\dagger}$ Johnson \& Johnson Vision Care, USA, \# Eurolens Research, University of Manchester, UK, ${ }^{\S}$ The Ocular Surface Institute, College of Optometry, University of Houston, Houston, TX, USA, ${ }^{\ddagger}$ School of Optometry, University of Alabama at Birmingham, Birmingham, AL, USA

Signaturedani Matan

Date farmani 16,2016 


\section{Declaration for the addition of a co-author}

I, LAlCS HMAN. N. SUBBARAMAN (print first, middle, last name) agree to the addition of Dr Dominik Papir ski as a co-author in our manuscript entitled "Microbial contamination of contact lens storage cases during daily wear use" (manuscript number: OVS15496R1) in recognition of his significant contributions to the statistical analysis (as per the stated authors list below).

I also agree that he meets the ICMJE (http://www.icmje.org/recommendations/browse/roles-andresponsibilities/defining-the-role-of-authors-and-contributors.html) author criteria.

Jaya Dantam* PhD, BOptom; David J McCanna* PhD; Lakshman N Subbaraman* PhD, BSOptom; Dominik Papinski* PhD; Carol Lakkis ${ }^{\dagger}$ PhD, PGCertOcTher, FAAO; Aftab Mirza ${ }^{\#}$ MSc, MCOptom; David A Berntsen", PhD, OD, FAAO; Philip Morgan\# PhD, MCOptom, FAAO; Jason J Nichols ${ }^{\ddagger} \mathrm{PhD}$, M.P.H, FAAO; Lyndon Jones* PhD, FCOptom, FAAO; for the Performance of Contact Lens Solutions Study Group

* Centre for Contact Lens Research, School of Optometry \& Vision Science, University of Waterloo, Canada, ${ }^{\dagger}$ Johnson \& Johnson Vision Care, USA, " Eurolens Research, University of Manchester, UK, ${ }^{\S}$ The Ocular Surface Institute, College of Optometry, University of Houston, Houston, TX, USA, ${ }^{\ddagger}$ School of Optometry, University of Alabama at Birmingham, Birmingham, AL, USA

Signature NV. Justee Date $\operatorname{San} 22,2016$ 


\section{Declaration for the addition of a co-author}

I, _ Carol Lakkis (print first, middle, last name) agree to the addition of Dr

Dominik Papinski as a co-author in our manuscript entitled "Microbial contamination of contact lens storage cases during daily wear use" (manuscript number: OVS15496R1) in recognition of his significant contributions to the statistical analysis (as per the stated authors list below).

I also agree that he meets the ICMJE (http://www.icmje.org/recommendations/browse/roles-andresponsibilities/defining-the=role-of-authors-and-contributors.html) author criteria.

Jaya Dantam* PhD, BOptom; David J McCanna* PhD; Lakshman N Subbaraman* PhD, BSOptom; Dominik Papinski* PhD; Carol Lakkis ${ }^{\dagger} \mathrm{PhD}$, PGCertOcTher, FAAO; Aftab Mirza ${ }^{\#}$ MSc, MCOptom; David A Berntsen ${ }^{\S}$, PhD, OD, FAAO; Philip Morgan ${ }^{\#}$ PhD, MCOptom, FAAO; Jason J Nichols ${ }^{\ddagger} \mathrm{PhD}$, M.P.H, FAAO; Lyndon Jones* PhD, FCOptom, FAAO; for the Performance of Contact Lens Solutions Study Group

* Centre for Contact Lens Research, School of Optometry \& Vision Science, University of Waterloo, Canada, ${ }^{\dagger}$ Johnson \& Johnson Vision Care, USA, \# Eurolens Research, University of Manchester, UK, ${ }^{\S}$ The Ocular Surface Institute, College of Optometry, University of Houston, Houston, TX, USA, ${ }^{\ddagger}$ School of Optometry, University of Alabama at Birmingham, Birmingham, AL, USA

Signature eelies

\section{Date 18 January 2016}




\section{Declaration for the addition of a co-author}

I, AFTAB MIRZA (print first, middle, last name) agree to the addition of Dr Dominik Papinski as a co-author in our manuscript entitled "Microbial contamination of contact lens storage cases during daily wear use" (manuscript number: OVS15496R1) in recognition of his significant contributions to the statistical analysis (as per the stated authors list below).

I also agree that he meets the ICMJE (http://www.icmje.org/recommendations/browse/roles-andresponsibilities/defining-the-role-of-authors-and-contributors.html) author criteria.

Jaya Dantam* PhD, BOptom; David J McCanna* PhD; Lakshman N Subbaraman* PhD, BSOptom; Dominik Papinski* PhD; Carol Lakkis ${ }^{\dagger}$ PhD, PGCertOcTher, FAAO; Aftab Mirza ${ }^{\#}$ MSc, MCOptom; David A Berntsen $\$$, PhD, OD, FAAO; Philip Morgan ${ }^{\sharp} \mathrm{PhD}$, MCOptom, FAAO; Jason J Nichols ${ }^{\ddagger} \mathrm{PhD}$, M.P.H, FAAO; Lyndon Jones* PhD, FCOptom, FAAO; for the Performance of Contact Lens Solutions Study Group

* Centre for Contact Lens Research, School of Optometry \& Vision Science, University of Waterloo, Canada, ${ }^{\dagger}$ Johnson \& Johnson Vision Care, USA, \# Eurolens Research, University of Manchester, UK, $\$$ The Ocular Surface Institute, College of Optometry, University of Houston, Houston, TX, USA, ₹ School of Optometry, University of Alabama at Birmingham, Birmingham, AL, USA

Signature

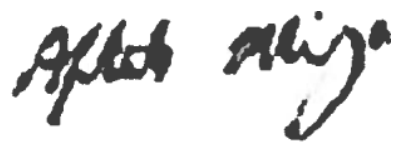

Date January 18, 2016 


\section{Declaration for the addition of a co-author}

I, __David A. Berntsen, OD PhD___ (print first, middle, last name) agree to the addition of Dr Dominik Papinski as a co-author in our manuscript entitled "Microbial contamination of contact lens storage cases during daily wear use" (manuscript number: OVS15496R1) in recognition of his significant contributions to the statistical analysis (as per the stated authors list below).

I also agree that he meets the ICMJE (http://www.icmje.org/recommendations/browse/roles-andresponsibilities/defining-the-role-of-authors-and-contributors.html) author criteria.

Jaya Dantam* PhD, BOptom; David J McCanna* PhD; Lakshman N Subbaraman* PhD, BSOptom; Dominik Papinski* PhD; Carol Lakkis ${ }^{\dagger} \mathrm{PhD}$, PGCertOcTher, FAAO; Aftab Mirza ${ }^{\#}$ MSc, MCOptom; David A Berntsen $\$$, PhD, OD, FAAO; Philip Morgan ${ }^{\#} \mathrm{PhD}$, MCOptom, FAAO; Jason J Nichols ${ }^{\ddagger} \mathrm{PhD}$, M.P.H, FAAO; Lyndon Jones* PhD, FCOptom, FAAO; for the Performance of Contact Lens Solutions Study Group

* Centre for Contact Lens Research, School of Optometry \& Vision Science, University of Waterloo, Canada, ${ }^{\dagger}$ Johnson \& Johnson Vision Care, USA, \# Eurolens Research, University of Manchester, UK, ${ }^{\S}$ The Ocular Surface Institute, College of Optometry, University of Houston, Houston, TX, USA, ${ }^{\ddagger}$ School of Optometry, University of Alabama at Birmingham, Birmingham, AL, USA

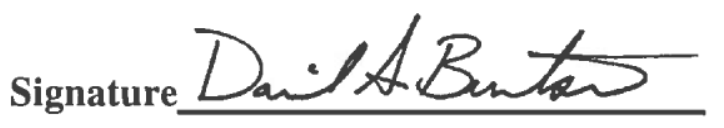

Date__1-19-16 


\section{Declaration for the addition of a co-author}

I, PHILIP B. MORGAN (print first, middle, last name) agree to the addition of Dr Dominik Papinski as a co-author in our manuscript entitled "Microbial contamination of contact lens storage cases during daily wear use" (manuscript number: OVS15496R1) in recognition of his significant contributions to the statistical analysis (as per the stated authors list below).

I also agree that he meets the ICMJE (http://www.icmje.org/recommendations/browse/roles-andresponsibilities/defining-the-role-of-authors-and-contributors.html) author criteria.

Jaya Dantam* PhD, BOptom; David J McCanna* PhD; Lakshman N Subbaraman* PhD, BSOptom; Dominik Papinski* PhD; Carol Lakkis ${ }^{\dagger} \mathrm{PhD}$, PGCertOcTher, FAAO; Aftab Mirza ${ }^{\#}$ MSc, MCOptom; David A Berntsen ${ }^{\S}$ PhD, OD, FAAO; Philip Morgan ${ }^{\sharp} \mathrm{PhD}$, MCOptom, FAAO; Jason J Nichols ${ }^{\ddagger}$ PhD, M.P.H, FAAO; Lyndon Jones* PhD, FCOptom, FAAO; for the Performance of Contact Lens Solutions Study Group

${ }^{*}$ Centre for Contact Lens Research, School of Optometry \& Vision Science, University of Waterloo, Canada, ${ }^{\dagger}$ Johnson \& Johnson Vision Care, USA, \# Eurolens Research, University of Manchester, UK, ${ }^{\S}$ The Ocular Surface Institute, College of Optometry, University of Houston, Houston, TX, USA, ${ }^{\ddagger}$ School of Optometry, University of Alabama at Birmingham, Birmingham, AL, USA

Signature P. Murgads

Date January 17, 2016 


\section{Declaration for the addition of a co-author}

I. TAtaw Niclot (print first, middle, last name) agree to the addition of $\mathrm{Dr}$ Dominik Papinski as a co-author in our manuscript entitled "Microbial contamination of contact lens storage cases during daily" wear use" (manuscript number: OVS15496R1) in recognition of his significant contributions to the statistical analysis (as per the stated authors list below).

I also agree that he meets the ICM.JE (http://www.icmje.org/reconimendations/browse/roles-andresponsibilities/defining-the-role-of-authors-and-contributors.html) author criteria.

Jaya Dantam* PhD, BOptom; David J McCanna* PhD; Lakshman N Subbaraman* PhD, BSOptom; Dominik Papinski* PhD; Carol Lakkis ${ }^{\dagger}$ PhD, PGCertOcTher, FAAO; Aftab Mirza ${ }^{4}$ MSc, MCOptom; David A Berntsen s PhD, OD, FAAO; Philip Morgan ${ }^{\hbar}$ PhD, MCOptom, FAAO; Jason J Nichols ${ }^{\ddagger}$ PhD, M.P.H, FAAO; Ly'ndon Jones* PlıD, FCOptom, FAAO; for the Performance of Contact Lens Solutions Study Group

* Centre for Conlact lens Research, School of Optometry \& Vision Science. University of Waterloo, Canada, Johuson \& Johnson Vision Care, USA, "Eurolens Research. University of Manchester, UK, 5 The Ocular Surface Institute, College of Optometry, University of I louston, Houston, TX, USA. `School of Oplometry, University of Alabama at Birmingham, Birmingham, AL, USA

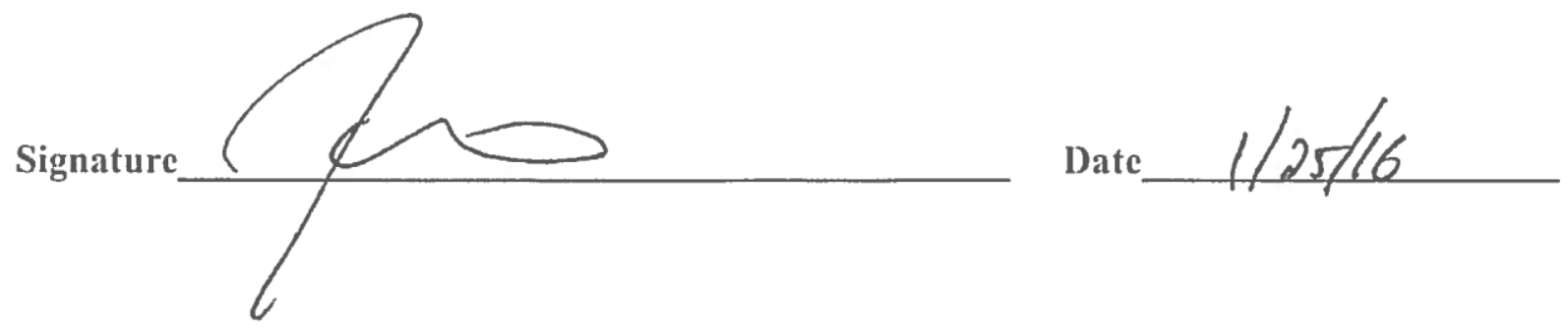




\section{Declaration for the addition of a co-author}

I, LY MboN doNG (print first, middle, last name) agree to the addition of Dr

Dominik Papinski as a co-author in our manuscript entitled "Microbial contamination of contact lens storage cases during daily wear use" (manuscript number: OVS15496R1) in recognition of his significant contributions to the statistical analysis (as per the stated authors list below).

I also agree that he meets the ICMJE (http://www.icmje.org/recommendations/browse/roles-andresponsibilities/defining-the-role-of-authors-and-contributors.html) author criteria.

Jaya Dantam* PhD, BOptom; David J McCanna* PhD; Lakshman N Subbaraman* PhD, BSOptom; Dominik Papinski* PhD; Carol Lakkis ${ }^{\dagger} \mathrm{PhD}$, PGCertOcTher, FAAO; Aftab Mirza\# MSc, MCOptom; David A Berntsen ${ }^{\S}$ PhD, OD, FAAO; Philip Morgan ${ }^{\#}$ PhD, MCOptom, FAAO; Jason J Nichols ${ }^{\ddagger} \mathrm{PhD}$, M.P.H, FAAO; Lyndon Jones* PhD, FCOptom, FAAO; for the Performance of Contact Lens Solutions Study Group

* Centre for Contact Lens Research, School of Optometry \& Vision Science, University of Waterloo, Canada, ${ }^{\dagger}$ Johnson \& Johnson Vision Care, USA, " Eurolens Research, University of Manchester, UK, § The Ocular Surface Institute, College of Optometry, University of Houston, Houston, TX, USA, ${ }^{\ddagger}$ School of Optometry, University of Alabama at Birmingham, Birmingham, AL, USA

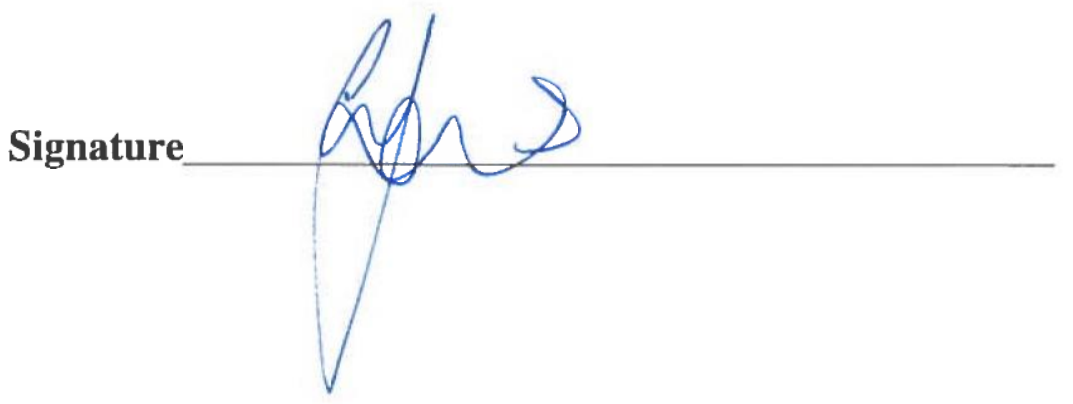

Date 15 JAN 2016 


\section{Declaration of contribution and authorship}

To qualify for authorship, for the manuscript \# OVS15496R1 entitled "Microbial contamination of contact lens storage cases during daily wear use", by checking the appropriate boxes below, I declare that I meet all the four ICMJE (http://www.icmje.org/recommendations/browse/roles-andresponsibilities/defining-the-role-of-authors-and-contributors.html) criteria, stated as follows:

$\nabla$ Substantial contributions to the conception or design of the work; or the acquisition, analysis, or interpretation of data for the work; AND

$\checkmark$ Drafting the work or revising it critically for important intellectual content; AND

$\square$ Final approval of the version to be published; AND

$\checkmark$ Agreement to be accountable for all aspects of the work in ensuring that questions related to the accuracy or integrity of any part of the work are appropriately investigated and resolved.

Print name (first, middle, last) J J J D DANTAM Signature $\quad \theta$ - Taye

Date Jan 15,2016 


\section{Declaration of contribution and authorship}

To qualify for authorship, for the manuscript \# OVS15496R1 entitled "Microbial contamination of contact lens storage cases during daily wear use", by checking the appropriate boxes below, I declare that I meet all the four ICMJE (http://www.icmje.org/recommendations/browse/rolesand-responsibilities/defining-the-role-of-authors-and-contributors.html) criteria, stated as follows:

$\downarrow$ Substantial contributions to the conception or design of the work; or the acquisition, analysis, or interpretation of data for the work; AND

$\square$ Drafting the work or revising it critically for important intellectual content; AND

Final approval of the version to be published; AND

$\checkmark$ Agreement to be accountable for all aspects of the work in ensuring that questions related to the accuracy or integrity of any part of the work are appropriately investigated and resolved.

$\begin{array}{llll}\text { Print name lirst, } & \text { middle, }\end{array}$

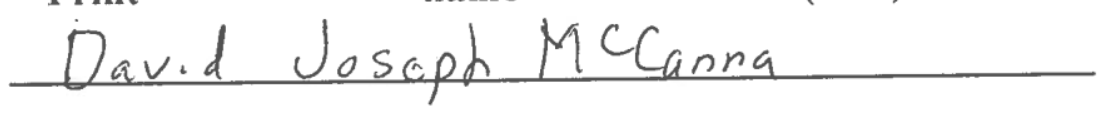

Signature Stanid Me Canna

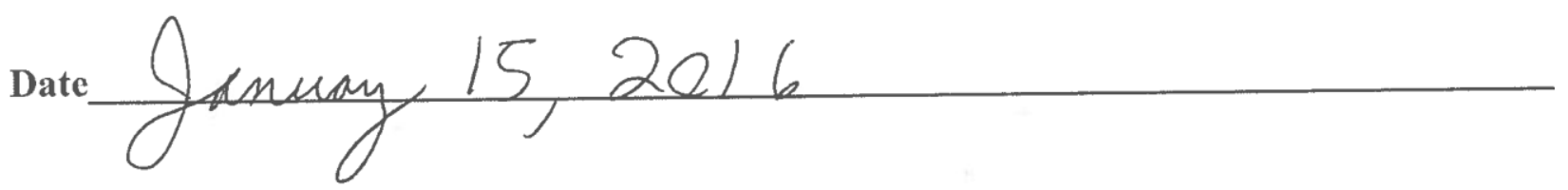


Declaration of contribution and authorship

To qualify for authorship, for the manuscript \# OVS15496R1 entitled "Microbial contamination of contact lens storage cases during daily wear use", by checking the appropriate boxes below, I declare that I meet all the four ICMJE (http://www.icmje.org/recommendations/browse/roles-andresponsibilities/defining-the-role-of-authors-and-contributors.html) criteria, stated as follows:

Substantial contributions to the conception or design of the work; or the acquisition, analysis, or interpretation of data for the work; AND

Drafting the work or revising it critically for important intellectual content; AND

5 Final approval of the version to be published; AND

Agreement to be accountable for all aspects of the work in ensuring that questions related to the accuracy or integrity of any part of the work are appropriately investigated and resolved.

Print name (first, middle, last) LAMIIMAN SUBBARAMAN Signature

Date Jan 22,2016 


\section{Declaration of contribution and authorship}

To qualify for authorship, for the manuscript \# OVS15496R1 entitled "Microbial contamination of contact lens storage cases during daily wear use", by checking the appropriate boxes below, I declare that I meet all the four ICMJE (http://www.icmje.org/recommendations/browse/roles-andresponsibilities/defining-the-role-of-authors-and-contributors.html) criteria, stated as follows:

Substantial contributions to the conception or design of the work; or the acquisition, analysis, or interpretation of data for the work; AND

$\square$ Drafting the work or revising it critically for important intellectual content; AND

$\square$ Final approval of the version to be published; AND

Agreement to be accountable for all aspects of the work in ensuring that questions related to the accuracy or integrity of any part of the work are appropriately investigated and resolved.

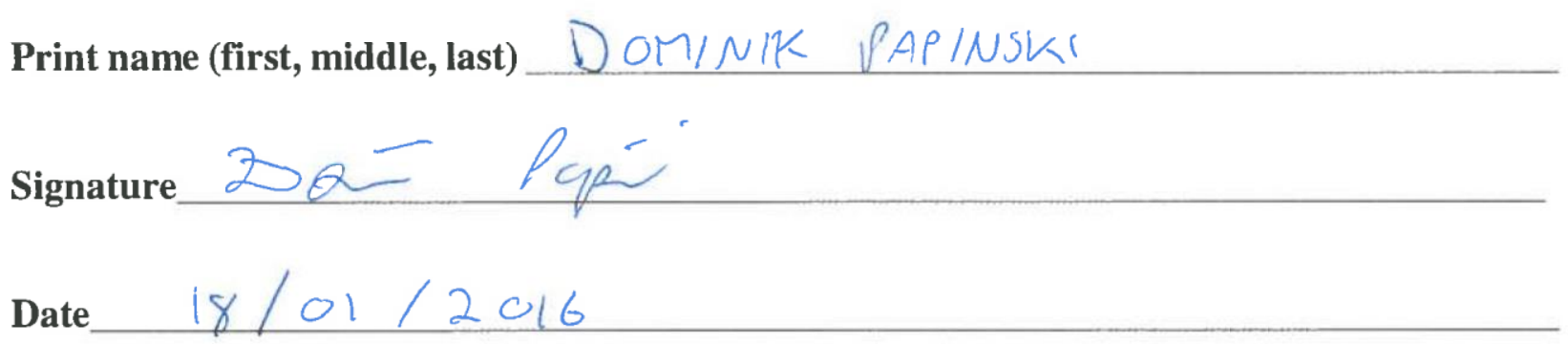




\section{Declaration of contribution and authorship}

To qualify for authorship, for the manuscript \# OVS15496R1 entitled "Microbial contamination of contact lens storage cases during daily wear use", by checking the appropriate boxes below, I declare that I meet all the four ICMJE (http://www.icmje.org/recommendations/browse/rolesand-responsibilities/defining-the-role-of-authors-and-contributors.html) criteria, stated as follows:

$\bigotimes$ Substantial contributions to the conception or design of the work; or the acquisition, analysis, or interpretation of data for the work; AND

Drafting the work or revising it critically for important intellectual content; AND

$\bigotimes$ Final approval of the version to be published; AND

$\triangle$ Agreement to be accountable for all aspects of the work in ensuring that questions related to the accuracy or integrity of any part of the work are appropriately investigated and resolved.

Print name (first, middle, last) Carol Lakkis

Signature $\operatorname{esclec}$

Date 18 January 2016 


\section{Declaration of contribution and authorship}

To qualify for authorship, for the manuscript \# OVS15496R1 entitled "Microbial contamination of contact lens storage cases during daily wear use", by checking the appropriate boxes below, I declare that I meet all the four ICMJE (http://www.icmje.org/recommendations/browse/rolesand-responsibilities/defining-the-role-of-authors-and-contributors.html) criteria, stated as follows:

$\otimes$ Substantial contributions to the conception or design of the work; or the acquisition, analysis, or interpretation of data for the work; AND

$\otimes$ Drafting the work or revising it critically for important intellectual content; AND

$\triangle$ Final approval of the version to be published; AND

$\nabla$ Agreement to be accountable for all aspects of the work in ensuring that questions related to the accuracy or integrity of any part of the work are appropriately investigated and resolved.

Print name (first, middle, last)

AFTAB MIRZA

Signature

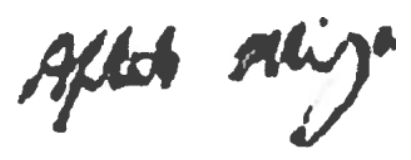

Date January 18, 2016 


\section{Declaration of contribution and authorship}

To qualify for authorship, for the manuscript \# OVS15496R1 entitled "Microbial contamination

of contact lens storage cases during daily wear use", by checking the appropriate boxes below, I declare that I meet all the four ICMJE (http://www.icmje.org/recommendations/browse/rolesand-responsibilities/defining-the-role-of-authors-and-contributors.html) criteria, stated as follows:

$\otimes$ Substantial contributions to the conception or design of the work; or the acquisition, analysis, or interpretation of data for the work; AND

$\otimes$ Drafting the work or revising it critically for important intellectual content; AND

$\triangle$ Final approval of the version to be published; AND

$\otimes$ Agreement to be accountable for all aspects of the work in ensuring that questions related to the accuracy or integrity of any part of the work are appropriately investigated and resolved.

Print name (first, middle, last) David A. Berntsen, OD PhD

Signature Daild Butos

Date 1-19-16 


\section{Declaration of contribution and authorship}

To qualify for authorship, for the manuscript \# OVS15496R1 entitled "Microbial contamination

of contact lens storage cases during daily wear use", by checking the appropriate boxes below, I declare that I meet all the four ICMJE (http://www.icmje.org/recommendations/browse/rolesand-responsibilities/defining-the-role-of-authors-and-contributors.html) criteria, stated as follows:

$\otimes$ Substantial contributions to the conception or design of the work; or the acquisition, analysis, or interpretation of data for the work; AND

$\bigotimes$ Drafting the work or revising it critically for important intellectual content; AND

$凶$ Final approval of the version to be published; AND

$\triangle$ Agreement to be accountable for all aspects of the work in ensuring that questions related to the accuracy or integrity of any part of the work are appropriately investigated and resolved.

Print name (first, middle, last)

PHILIP B. MORGAN

signature P. Margath

Date January 17, 2016 


\section{Declaration of contribution and authorship}

To qualify for authorship, for the manuscript \# OVS15496R1 entitled "Microbial contamination of contact lens storage cases during daily wear use", by checking the appropriate boxes below, I declare that I meet all the four ICM.JE (http://www.icmje.org/recommendations/browse/roles-ar dresponsibilities/defining-the-role-of-authors-and-contributors.html) criteria, stated as follows:

Substantial contributions to the conception or design of the work; or the acquisition, analysis, or interpretation of data for the work; AND

Drafting the work or revising it critically for important intellectual content; AND Final approval of the version to be published; AND

Agreement to be accountable for all aspects of the work in ensuring that questions related to he accuracy or integrity of any part of the work are appropriately investigated and resolved.

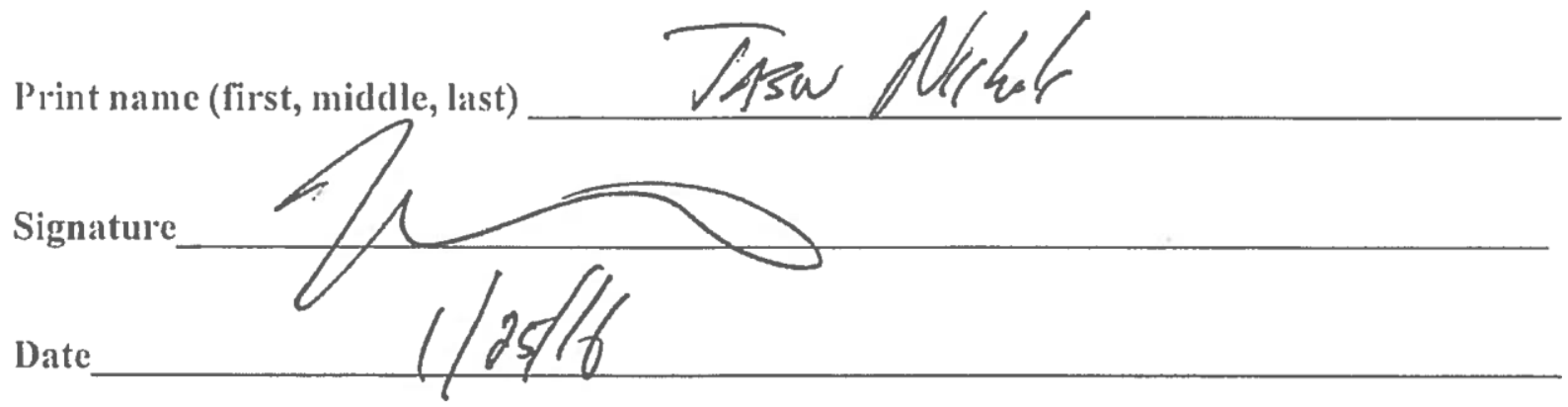


Declaration of contribution and authorship

To qualify for authorship, for the manuscript \# OVS15496R1 entitled "Microbial contamination of contact lens storage cases during daily wear use", by checking the appropriate boxes below, I declare that I meet all the four ICMJE (http://www.icmje.org/recommendations/browse/roles-andresponsibilities/defining-the-role-of-authors-and-contributors.html) criteria, stated as follows:

Substantial contributions to the conception or design of the work; or the acquisition, analysis, or interpretation of data for the work; AND

Drafting the work or revising it critically for important intellectual content; AND

Final approval of the version to be published; AND

Agreement to be accountable for all aspects of the work in ensuring that questions related to the accuracy or integrity of any part of the work are appropriately investigated and resolved.

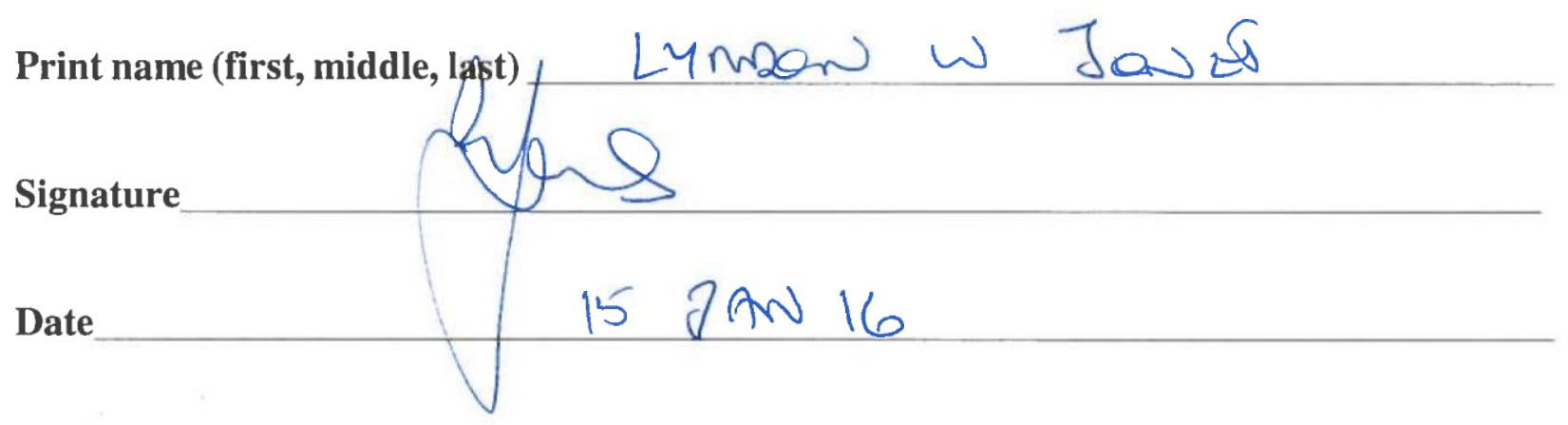




\section{MICROBIAL CONTAMINATION OF CONTACT LENS STORAGE CASES DURING DAILY WEAR USE}

Jaya Dantam* PhD, BOptom; David J McCanna* PhD; Lakshman N Subbaraman* PhD, BSOptom; Dominik Papinski* PhD; Carol Lakkist PhD, PGCertOcTher, FAAO; Aftab Mirza ${ }^{\#}$ MSc, MCOptom;

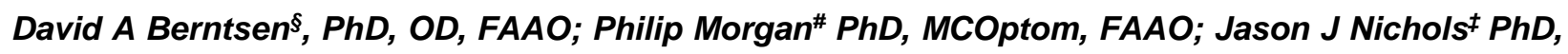
M.P.H, FAAO; Lyndon Jones* PhD, FCOptom, FAAO; for the Performance of Contact Lens Solutions Study Group

* Centre for Contact Lens Research, School of Optometry \& Vision Science, University of Waterloo, Canada, ${ }^{\dagger}$ Johnson \& Johnson Vision Care, USA, \# Eurolens Research, University of Manchester, UK, § The Ocular Surface Institute, College of Optometry, University of Houston, Houston, TX, USA, ¥ School of Optometry, University of Alabama at Birmingham, Birmingham, AL, USA

Number of tables: 3

Number of Figures: 3

Address of Corresponding author: Dr. Jaya Dantam

Centre for Contact Lens Research, 200 Columbia St west, University of Waterloo, Waterloo N2L 3G1, Canada

Fax number: +15198884303

Email address: jaya.dantam@gmail.com

Date of revised version2 submission: Jan 29, 2016 
Purpose: To evaluate contact lens (CL) storage case contamination when used with four different CL care solutions, during daily wear of three different CL materials.

Methods: A parallel, prospective, bilateral, randomized clinical trial $(n=38)$ was conducted. Subjects were randomly assigned to use one of three $C L$ materials (etafilcon $A$, senofilcon $A$ or galyfilcon $A$ ) on a daily wear basis. Subsequently, each subject randomly used one of four different CL care solutions (Biotrue, OPTI-FREE PureMoist, RevitaLens OcuTec and CLEAR CARE) for two weeks, along with their respective storage cases. After every two-week period, their storage cases were collected and the right and left wells of each storage case were randomized for two procedures: (i) microbial enumeration by swabbing the storage case surface and (ii) evaluation of biofilm formation (multipurpose solution cases only) using a crystal violet staining assay.

Results: More than $80 \%$ of storage cases were contaminated when used in conjunction with the four $\mathrm{CL}$ care solutions, irrespective of the CL material worn. Storage cases maintained with CLEAR CARE (mean Log colony forming units $(C F U) /$ well $\pm S D, 2.0 \pm 1.0)$ revealed significantly $(p<0.001)$ greater levels of contamination, compared to those maintained with Biotrue $(1.3 \pm 0.8)$ and RevitaLens OcuTec $(1.2 \pm 0.8)$. Predominantly, storage cases were contaminated with Gram-positive bacteria $(\geq 80 \%)$. There were significant differences $(\mathrm{p}=0.013)$ for the levels of Gram-negative bacteria recovered from the storage cases maintained with different CL care solutions. Storage cases maintained with OPTI-FREE PureMoist (0.526 \pm 0.629 ) showed significantly higher biofilm formation $(p=0.028)$ compared to those maintained with Biotrue $(0.263 \pm 0.197)$.

Conclusions: Levels of contamination ranged from 0 to 6.4 Log CFU/storage case well, which varied significantly $(p<0.001)$ between different $C L$ care solutions and storage case contamination was not modulated by CL materials.

Key words: contact lens, storage case, solution, contamination, biofilm, bacteria 


\section{INTRODUCTION}

2 Approximately 140 million people worldwide and 40.939.2 million people in the United States use contact

3 lenses (CLs) as a vision correction aid. ${ }^{1}$ Contact lens wear has been associated with a variety of ocular

4 complications, including sight threatening complications such as microbial keratitis (MK). ${ }^{2}$ When used on a

5 daily wear basis, the incidence of MK varies between 2.2 and 6.9 per 10,000 wearers. ${ }^{3,4}$ The majority of

6 CL-related MK are caused by Gram-negative bacteria, ${ }^{5,6}$ with Pseudomonas aeruginosa frequently being

7 recovered from culture-positive corneal scrapings. ${ }^{2,6-11}$ Given the widespread use of CLs, ${ }^{12}$ even a low

8 incidence of MK incurs substantial public health concerns. During CL wear, microbial contamination of CLs

9 and their associated care solutions and storage cases is a common finding. ${ }^{13-17}$ Of particular note is 10 contamination of the storage cases, ${ }^{14,18}$ which occurs far more frequently than contamination of either the

$11 \mathrm{CL}^{14}, 18$ or disinfection solutions. ${ }^{14}$ Additionally, studies have indicated that the leading causative

12 microorganism ' $P$. aeruginosa' that was recovered from corneal scrapings of patients with MK has been

13 traced to storage cases. ${ }^{19,20}$ Furthermore, certain retrospective studies ${ }^{21,22}$ have suggested that culturing

14 either the $\mathrm{CL}^{21,22}$ or storage case,,$^{23}$ in the event of negative or unavailable corneal cultures, may facilitate

15 the identification of the microorganisms causing MK. Recently, certain emerging Gram-negative bacterial

16 genera such as Achromobacter, Stenotrophomonas and Delftia have been recovered from CL storage

17 cases $^{24}$ and associated with cases of $\mathrm{MK}$ in $\mathrm{CL}$ wearers. ${ }^{25}$ Taken together, these findings indicate the notable role that storage cases contaminated with Gram-negative bacteria may play in the pathogenesis of 19 MK.

Irrespective of the care solutions used, microbial contamination of storage cases ranges from $19 \%$ to

$2192 \% .^{13,14,16,17,26-33}$ Often, the contaminated storage cases illustrate polymicrobial colonization, with varying

22 frequencies of bacteria, fungi and protozoa. ${ }^{17,28,34}$ Willcox et al. reported that in addition to the levels of 23 contamination, the spectrum of microbes recovered from the contaminated storage cases varied with the 24 different formulations of disinfecting solutions. ${ }^{17}$ Recently, manufacturers have introduced multipurpose 25 disinfecting solutions (MPDS) with newly formulated dual disinfectants, in an attempt to increase the 26 efficacy of the CL care solutions. However, controlling storage case contamination remains a challenge, 27 even with disinfecting solutions that contain dual disinfectants. ${ }^{17}$ 
Practitioners recommend a wide variety of care solutions and CL material combinations, which may vary in their ability to resist microbial contamination of their respective storage cases. The purpose of this study was to determine the frequency and levels of microbial contamination in storage cases used with different CL material and care solution combinations, during a two-week exposure period. Further, this study aimed to classify the type of microorganisms recovered from storage cases and to quantify the biofilm formation on the interior surface of storage cases used with a variety of MPDS.

MATERIALS AND METHODS

\section{Contact Lens Care Solutions, Storage Cases and Contact Lenses}

The four care solutions used in this study are listed in Table 1. All care solutions were supplied with their respective storage cases by the manufacturers. A hydrogel material (etafilcon A; ACUVUE 2; Johnson \& Johnson Vision Care, Inc.) and two silicone hydrogel materials (ACUVUE OASYS; senofilcon A; and ACUVUE Advance Plus; galyfilcon A; Johnson \& Johnson Vision Care, Inc.) were used in this study.

\section{Clinical Study Design}

As part of an international multi-site clinical study consisting of 236 subjects (sites were Eurolens Research, University of Manchester, UK, the Ocular Surface Institute, College of Optometry, University of Houston, USA and the Centre for Contact Lens Research, University of Waterloo, Canada) assessing the clinical performance of contemporary care systems, a sub-set of subjects at the University of Waterloo $(n=38)$ were included in a parallel study to specifically address the issue of case contamination. This was a cross-over, bilateral, and randomized clinical study with nine scheduled visits. All study procedures were conducted in compliance with the International Conference on Harmonization Good Clinical Practice E6 (ICH-GCP) guidelines, tenets of Declaration of Helsinki for Experimentation in Humans and applicable regulatory requirements.

Subjects between 18 and 69 years of age with previous CL wear experience and who had no systemic or ocular contraindications for CL wear were enrolled in the study, after obtaining informed consent. After the initial random assignment to one of the three CL materials (which were worn on a daily wear basis), subjects were assigned to use one of the four care solutions in a random order for two-weeks, along with their 
respective storage cases. In addition to verbal instructions, subjects were given an instruction guide with regards to the use of their CLs and storage cases, specific to a care solution. After the initial two-week period, subjects were randomly assigned the remaining three care solutions, each for two weeks of use. The storage cases were collected after every two-week period. There was a washout period of at least four days between the care solutions, during which the subjects wore daily disposable CL (1-DAY ACUVUE MOIST; etafilcon A; Johnson \& Johnson Vision Care, Inc) and/or spectacles. All subjects were masked to the CL material assigned and the care solutions were de-identified as much as possible. This was achieved by removing the identifying manufacturer labels from the $C L$ care solution bottles. Complete masking of solution identification was not possible for either OPTI-FREE PureMoist (that has the manufacturer name embossed on the upper portion of the bottle) or CLEAR CARE (which uses a barrel-shaped storage case with platinum disk). The investigators were masked to the CL material only. Subjects were also masked as to the reason for their cases being collected and their subsequent culturing, to ensure that they did not modify their habitual behaviors during the study period, by instructing them to return all the study supplies at the end of each wearing period.

\section{Microbial Analysis of Contact Lens Storage Cases}

Storage cases were collected from subjects by the lab investigators and processed within two hours. All cases were handled aseptically while performing the microbial procedures. Prior to analysis, any residual care solution was discarded; however, no additional rinsing or neutralization steps were performed. The interior surface of a randomly selected well of the flat storage case and the inner surface of the lid were swabbed using a calcium alginate swab, pre-moistened with sterile phosphate buffered saline (PBS). For the barrel (stand-up) storage cases (used with the hydrogen-peroxide solution), one CL storage basket was randomly selected and the CL holder, interior and exterior surfaces of the CL basket, top hinge and the interior surface of the lid were swabbed. The swab was placed in a sterile plastic vial containing $2 \mathrm{~mL}$ PBS containing $1 \%$ sodium hexametaphosphate, which was vortexed at high speed for 30 seconds. From this sample, aliquots were removed and plated (up to 3 dilutions) on two sets of chocolate blood agar plates (without antibiotics or supplements) and a set of Sabouraud Dextrose agar (SAB) with Chloramphenicol 
81 incubated at $37^{\circ} \mathrm{C}$, one set under aerobic $\left(\mathrm{O}_{2}\right)$ conditions for 7 days and the other under anaerobic 82 conditions $\left(\mathrm{ANO}_{2}\right)$ for 4 days. The $\mathrm{SAB}$ with chloramphenicol plates were incubated at $25^{\circ} \mathrm{C}$ for 7 days. The colony forming units (CFUs) were enumerated after the designated incubation period. For bacterial isolates

84 recovered from aerobic and anaerobic cultures, Gram-staining was performed to classify their group, either as Gram-positive or Gram-negative, from the representative colonies of similar morphology and these data were combined for analysis. Fungal isolates were identified based on their morphological characteristics.

87 Additionally, a biofilm assay ${ }^{30,35}$ was performed with flat-bottomed cases only. Following the aforementioned microbial procedures on one of the wells, each storage case was air dried in an upside down position, allowing the evaporation of any residual moisture. The second (unswabbed) well was stained with $5 \%$ crystal violet stain for 45 minutes at room temperature, followed by a gentle wash with running tap water.

91 The biofilms were then extracted using 95\% ethanol. Finally, the solubilized biofilm extracts were transferred into 24-well microtiter plates and the absorbance of the samples was measured at $595 \mathrm{~nm}$, using a spectrophotometer (Thermo Scientific Multiskan Spectrum, USA).

\section{Statistical Analysis:}

A chi-square test was used to evaluate the differences in the frequency of microbial contamination of storage cases maintained with different care solutions. The levels of contamination (CFUs) were log transformed for the data analysis. For the exploration of biofilm data, absorbance values were used. Both the level of contamination and biofilm formation in storage cases were analyzed using a linear mixed model to compare the differences between care solutions. The model included CL material, care solution and the interaction between $C L$ and solution along with sequence of $C L$ care solution and visit (as appropriate) as

101 fixed effect factors. All these factors were tested simultaneously. Age and gender were not included in the 102 model. A Bonferroni correction was used for multiple pairwise comparisons. Only those factors that were 103 significant in the model were reported in the results section. All statistical tests were two-sided and 104 conducted at the $5 \%$ level of significance. Statistical software SPSS (IBM SPSS Statistics for Windows, 105 Version 22.0. Armonk, NY) was used for the data analysis.

\section{RESULTS}


Of the 38 subjects included in this study, $76 \%$ were female and $24 \%$ were male. The majority of subjects were university students. The mean age $( \pm S D)$ of the subjects was $30 \pm 11$ years. A total of 152 storage cases (as each subject used four different CL care solutions) were sampled and analyzed.

At least $80 \%$ of the storage cases cultured were contaminated (Figure 1), and the frequency of

111 contamination did not vary significantly between different solutions $(p=0.134)$, regardless the $C L$ material

112 combination, Table 2. The highest percentage of contamination was found in storage cases maintained 113 with OPTI-FREE PureMoist (98\%); those maintained with RevitaLens OcuTec exhibited the lowest 114 contamination (80\%). Figure 2 details the levels of contamination, which varied significantly between the 115 four $C L$ care solutions $(p<0.001)$.

116 Microorganisms recovered from the storage cases were classified by their group (either bacteria or fungi) 117 and subsequently bacteria were classified by their type (Figure 3). Levels of Gram-positive bacteria 118 recovered from the storage cases differed significantly $(p<0.001)$ between different $C L$ care solutions and 119 the specific comparisons between different storage cases are shown in Table 3. The levels of Gram120 negative bacteria recovered from different storage cases varied significantly $(p=0.013)$, between different 121 CL care solutions. The storage cases maintained with OPTI-FREE PureMoist (mean Log CFU/ storage 122 case well $\pm \mathrm{SD}, 0.3 \pm 0.9$ ) showed significantly higher levels of Gram-negative bacteria compared to those 123 maintained with Biotrue and CLEAR CARE, which each showed no recovery of Gram-negative bacteria 124 ( $p=0.026$ and $p=0.028$ respectively). The levels of Gram-negative bacteria recovered from the storage 125 cases maintained with RevitaLens OcuTec (mean Log CFU/ storage case well \pm SD, $0.1 \pm 0.3$ ) were not 126 significantly different compared to the storage cases maintained with any of the other three solutions (all $127 \mathrm{p}>0.05)$. There was statistically significant effect of visit on Gram-negative bacteria contamination $128(p=0.009)$, however post-hoc comparisons showed no significance between the different visits $(p>0.05)$. 129 For fungi, the number of observations was limited, preventing valid statistical comparisons.

130 The biofilm formation on the three flat cases varied significantly between products $(p=0.031)$. Higher 131 absorbance values refer to greater biofilm formation on the surface of storage cases. Storage cases 132 maintained with OPTI-FREE PureMoist (mean absorbance \pm SD $=0.526 \pm 0.629$ ) showed significantly 133 greater biofilm formation compared to those maintained with Biotrue $(0.263 \pm 0.197 ; p=0.028)$. However, 
134 the storage cases maintained with RevitaLens OcuTec $(0.362 \pm 0.300)$ did not vary significantly from the 135 other two solutions ( $p>0.05)$.

\section{DISCUSSION}

137 A variety of care solutions are commercially available for the care and maintenance of reusable hydrogel 138 and silicone hydrogel CL materials, leading to a wide-range of combinations of materials and care solutions 139 being used in clinical practice. This study evaluated the microbial contamination of storage cases 140 maintained with three contemporary dual disinfectant multipurpose solutions and a hydrogen peroxide 141 based solution, when used with contemporary CL materials.

142 The results of the current study indicated that differences between CL materials did not impact microbial 143 contamination of the storage cases, which has previously been reported by Willcox et al. ${ }^{17}$ At least $80 \%$ of 144 the storage cases were contaminated (Figure 1), with no significant differences between the MPDS and the 145 peroxide-based system.

146 These contamination rates are consistent with recent studies that have reported the frequency of 147 contamination to be between $76 \%$ and $92 \%$, when storage cases were maintained with MPDSs containing 148 either polyhexanide- $0.0001 \%$ or polyquarternium- $10.001 \%+$ myristamindopropyl dimethylamine $0.0005 \%$ 149 or a hydrogen peroxide based CL care solution. ${ }^{17,30}$ In contrast, other studies have reported lower case 150 contamination rates of $42-66 \% .^{16,25,36,37}$ These variations could be attributable to the different study designs 151 or locations from where the cases were sampled. For example, while processing flat-bottomed cases, 152 certain studies swabbed the inner wells and the inner surface of the lids, ${ }^{17,30}$ whereas others swabbed the 153 inner base of the well and along the top rim, ${ }^{16,37}$ which may underestimate the frequency of contamination.

154 The sampling methods used in this study are consistent with those reported by Willcox et al., and Dantam 155 et al., ${ }^{17,30}$ and the results are broadly in agreement. Given that storage cases were only used for two weeks, 156 the contamination rates appear high. However, a previous study by Lakkis et al., ${ }^{38}$ also reported heavy 157 contamination of storage cases within two-weeks of use, irrespective of the care solutions used.

158 The levels of contamination in the storage cases ranged from 0 to 6.4 Log CFU/storage case well (Figure 159 2). This is within the values previously reported, which vary from 0 to 7.0 log CFU/per sample. ${ }^{16,17,29,34}$ The 
microorganism load recovered from the storage cases maintained with CLEAR CARE (mean Log CFU/ storage case well $\pm S D, 2.0 \pm 1.0)$ were significantly greater than those maintained with Biotrue $(1.3 \pm 0.8)$ and RevitaLens OcuTec $(1.2 \pm 0.8)$ solutions; however, the magnitude of the difference was less than 1.0 log, which may not be clinically relevant. ${ }^{39}$ The greater level of contamination with CLEAR CARE was driven by the degree of Gram-positive contamination. This observation is consistent with earlier studies, ${ }^{28,40,41}$ which reported heavier contamination with peroxide-based care systems when compared to chemical disinfection systems. More recently, Jiang et al. identified that peroxide-based systems were associated with frequent storage case contamination. ${ }^{23}$ However, in contrast, Wilson et al reported a lower incidence of contamination with the use of peroxide-based solutions. ${ }^{26}$ This increased microbial contamination of cases from hydrogen-peroxide based solutions has been attributed to 'catalase', an enzyme found in the intracellular contents of certain microorganisms, which breaks down hydrogen peroxide to water and oxygen, potentially limiting the activity of $3 \%$ hydrogen peroxide. ${ }^{28}$ Although the levels of Gram negative bacterial contamination varied significantly between different $C L$ care solutions $(p=0.013)$, the magnitude of the difference was less than $1.0 \log$ and this may not be clinically relevant. Further, the statistical significance of visit for Gram-negative bacterial contamination was limited to main effects only. The positive findings for Gram-negative bacteria contamination had maximum observations at visit 9 and this may be attributed to diminished compliance. However, this study was not designed to evaluate compliance and this is a limitation of the current study. As all the CL care solutions were randomly assigned, the sequences of CL care solutions were unbiased across all the visits.

In the current study, the bacteria recovered from storage cases were categorized based on the Gramstaining technique only, which is a limitation of this study. Given the relevance of Gram-negative bacteria in the occurrence of CL-related microbial keratitis, for future studies, it would also be worthwhile to consider and incorporate the identification of specific bacterial species of each recovered microorganism, including screening for Acanthamoeba species and exploring the effects of age and gender on case contamination.

In the current study, biofilm formation within the flat storage cases was investigated using an established crystal-violet staining technique. ${ }^{30,35}$ Biofilms were evident (Figure 4), particularly in storage cases maintained with OPTI-FREE PureMoist, which demonstrated significantly higher biofilm formation on the 
case surface compared to those maintained with Biotrue $(p=0.028)$. The scientific/clinical relevance of the biofilm levels observed in this study are yet to be established; however, biofilms are common in CL storage cases that exhibit persistent microbial contamination. ${ }^{10,17,31}$ In the sessile form, microbial cells are more resistant to care solutions in-vivo ${ }^{26}$ and in-vitro ${ }^{42}$ compared to their planktonic phenotype ${ }^{43}$ It is interesting to note that the current recommendations from ISO1472944 and the FDA 510(k) document for premarket

192 approval of CL care solutions ${ }^{45}$ are limited to the evaluation of antimicrobial efficacy against selective 193 reference strains of planktonic bacteria and fungi only. As previously identified in some in-vitro studies, ${ }^{42,43}$ 194 the data from this in-vivo study also suggests that there is a need to consider the inclusion of some form of 195 assessment of solution activity against microbes encapsulated in a biofilm, or adoption of other strategies 196 to reduce CL case contamination, such as antimicrobial lens cases or increased case replacement 197 frequency.

A recent clinical study demonstrated that enhanced verbal and written advice on the importance of appropriate storage case hygiene can improve patient compliance. ${ }^{46}$ Additionally, in-vitro ${ }^{47}$ and clinical ${ }^{36,48}$ studies have suggested that incorporation of additional steps compared to those traditionally recommended by the manufacturers such as rubbing, rinsing with the care solution and tissue-wiping during the daily maintenance of storage cases can substantially decrease bacterial loads, including biofilms. ${ }^{47,49,50}$ Thus, 203 future studies may consider factors such as practitioners' instructions on care regimen use, ${ }^{46,48,51}$ subjects' 204 behavioral patterns towards CL care and maintenance ${ }^{36,5252}$ and environmental conditions, to acquire a 205 comprehensive understanding of the multifactorial processes involved in the microbial contamination of storage cases.

207 It is important to note that these findings are based on a two-week period only and further studies are 208 necessary to establish the rates and degree of contamination associated with longer term exposure. In 209 addition, the association between microbial contamination and the occurrence of adverse events during CL 210 wear is worthy of future study, along with the potential role that self-limiting "disposable" cases and/or 211 antibacterial cases may have on such adverse events.

212 In conclusion, despite the recent introduction of new care systems into the market, data from this study 213 would suggest that there has been little impact on the microbial contamination rate of CL storage cases, as 
214 the percentage of cases that were contaminated was at least $80 \%$, even with contemporary MPDSs with 215 dual disinfection systems. The levels of microbial contamination ranged widely, from 0 to 6.4 Log 216 CFU/storage case well, which varied significantly between care solutions, with predominant recovery of 217 gram-positive bacteria. Contamination rates were unrelated to the CL material worn. 
241 The authors thank Dr. Ulrike Stahl for providing statistical help and advice.

242 This study was funded by Johnson \& Johnson Vision Care, Inc.

243 Performance of Contact Lens Solutions Study Group

244 University of Houston Site

245 Jason J. Nichols, OD, MPH, PhD, FAAO; David A. Berntsen, OD, PhD, FAAO; Jessica H. Mathew, OD, 246 PhD, FAAO; Stephanie M. Cox, OD, FAAO; Katherine M. Bickle, OD, MS; Daniel R. Powell, OD, PhD; 247 Jared Cox, OD; William L. Miller, OD, PhD, FAAO; Ashley Wallace-Tucker, OD, FAAO; Sabrina Charrier, 248 OD, FAAO; Yi-Ju (Tina) Chen, BA, MA; Laura Cardenas; Sonia Huerta, AAS; Karen Dionne, BS

249 University of Manchester Site

250 Philip B. Morgan, PhD, MCOptom, FAAO, FBCLA; Carole Maldonado-Codina, PhD, MCOptom, FAAO, 251 FBCLA; Andrew J. Plowright, BSc(Hons), MSc, FBCLA; Gillian F. Howarth, BSc(Hons), MCOptom; Neil 252 Chatterjee, MSc, MCOptom; Aftab Mirza, MSc, MCOptom; Sarah Smith, BSc(Hons), MCOptom

253 University of Waterloo Site

254 Lyndon W. Jones, PhD, FCOptom, FAAO; Clinical Team: Kathy Dumbleton, PhD, MCOptom, FAAO; Marc 255 Schulze, PhD, Dipl Ing (AO), FAAO; Amir Moezzi, MSc, OD; Doerte Luensmann, PhD, Dipl. Ing. (AO), 256 FAAO; William Ngo, BSc, OD, FAAO; Lindsay Paquette, BSc, OD; Sruthi Srinivasan, PhD, BS Optom, 257 FAAO; Jalaiah Varikooty, MSc, BMed; Jane Johnson; Marina Simpson, BRT, Brad; Leona Voss; Lynn 258 Ryan, BA; Nadeera Careless; Alexandra Smith; Laboratory Team: Lakshman Subbaraman, PhD, BS 259 Optom, FAAO; Miriam Heynen, MSc; Jaya Dantam, PhD, BOptom; David McCanna, PhD; Negar Babaei 260 Omali, PhD, BOptom; Dominik Papinski, PhD

261 Johnson \& Johnson Vision Care, Inc.

262 Sheila B. Hickson-Curran, BSc(Hons), MCOptom, FAAO, FBCLA; Carol Lakkis, BScOptom, PhD, 263 PGCertOcTher, FAAO, FACO, FBCLA; Youssef Toubouti, MSc; Zohra Fadli, PhD; Mark Witold Lada, PhD 


\section{Financial Disclosures}

265 Over the past three years, research support or lectureship honoraria have been received from the following 266 companies as indicated by study site. University of Houston: Alcon, Allergan, Bausch + Lomb, Johnson \& 267 Johnson Vision Care, Menicon. University of Manchester: Alcon, Bausch + Lomb, CooperVision, Essilor, 268 Johnson \& Johnson Vision Care, Sauflon Pharmaceuticals, Ultravision. University of Waterloo: Advanced 269 Vision Research, Alcon, AlgiPharma, Allergan, CIBA Vision, CooperVision, Essilor, Johnson \& Johnson 270 Vision Care, Ocular Dynamics, Oculus, Ocusense, TearScience, and Visioneering Technologies. LWJ is a 271 consultant and/or serves on an advisory board for Alcon and J\&J Vision Care.

272

273

274

275

276

277 
291 1. Nichols JJ. Contact lenses 2015. Contact Lens Spectrum 2015;31 (January 2016):18-23, 55.

292 2. Lam J, Tan G, Tan DT, Mehta JS. Demographics and behaviour of patients with contact lens293 related infectious keratitis in singapore. Ann Acad Med Singapore 2013;42:499-506.

294 3. Stapleton F, Keay L, Edwards K, Naduvilath T, Dart JK, Brian G, Holden BA. The incidence of 295 contact lens-related microbial keratitis in Australia. Ophthalmology 2008;115:1655-62.

296 4. Morgan PB, Efron N, Hill EA, Raynor MK, Whiting MA, Tullo AB. Incidence of keratitis of varying 297 severity among contact lens wearers. Br J Ophthalmol 2005;89:430-6.

298 5. Schein OD, Ormerod LD, Barraquer E, Alfonso E, Egan KM, Paton BG, Kenyon KR. Microbiology 299 of contact lens-related keratitis. Cornea 1989;8:281-5.

$300 \quad 6 . \quad$ Stapleton F, Keay LJ, Sanfilippo PG, Katiyar S, Edwards KP, Naduvilath T. Relationship between 301 climate, disease severity, and causative organism for contact lens-associated microbial keratitis in 302 Australia. Am J Ophthalmol 2007;144:690-8.

303 7. Cheng KH, Leung SL, Hoekman HW, Beekhuis WH, Mulder PGH, Geerards AJM, Kijlstra A. 304 Incidence of contact-lens-associated microbial keratitis and its related morbidity. Lancet 1999;354:181-5.

305 8. Stapleton F, Dart JK, Seal DV, Matheson M. Epidemiology of Pseudomonas aeruginosa keratitis 306 in contact lens wearers. Epidemiol Infect 1995;114:395-402.

307 9. Bourcier T, Thomas F, Borderie V, Chaumeil C, Laroche L. Bacterial keratitis: predisposing factors, 308 clinical and microbiological review of 300 cases. Br J Ophthalmol 2003;87:834-8.

309 10. Lam DS, Houang E, Fan DS, Lyon D, Seal D, Wong E, Hong Kong Microbial Keratitis Study G. 310 Incidence and risk factors for microbial keratitis in Hong Kong: comparison with Europe and North America. 311 Eye (Lond) 2002;16:608-18.

312 11. Green M, Apel A, Stapleton F. Risk factors and causative organisms in microbial keratitis. Cornea $313 \quad 2008 ; 27: 22-7$.

314 12. Bennett ES. GP Annual report. Contact Lens Spectrum 2011;26 (October 2011):28-33, 48.

315 13. Boost MV, Cho P. Microbial flora of tears of orthokeratology patients, and microbial contamination 316 of contact lenses and contact lens accessories. Optom Vis Sci 2005;82:451-8. 
317 14. Yung MS, Boost M, Cho P, Yap M. Microbial contamination of contact lenses and lens care 318 accessories of soft contact lens wearers (university students) in Hong Kong. Ophthalmic Physiol Opt $319 \quad 2007 ; 27: 11-21$.

320 15. Collins M, Coulson J, Shuley V, Bruce A. Contamination of disinfection solution bottles used by 321 contact lens wearers. CLAO J 1994;20:32-6.

322 16. Wu YT, Zhu H, Harmis NY, Iskandar SY, Willcox M, Stapleton F. Profile and frequency of microbial 323 contamination of contact lens cases. Optom Vis Sci 2010;87:E152-8.

324 17. Willcox MD, Carnt N, Diec J, Naduvilath T, Evans V, Stapleton F, Iskandar S, Harmis N, de la Jara 325 PL, Holden BA. Contact lens case contamination during daily wear of silicone hydrogels. Optom Vis Sci $326 \quad 2010 ; 87: 456-64$

327 18. McLaughlin-Borlace L, Stapleton F, Matheson M, Dart JK. Bacterial biofilm on contact lenses and 328 lens storage cases in wearers with microbial keratitis. J Appl Microbiol 1998;84:827-38.

329 19. Mayo MS, Schlitzer RL, Ward MA, Wilson LA, Ahearn DG. Association of Pseudomonas and 330 Serratia corneal ulcers with use of contaminated solutions. J Clin Microbiol 1987;25:1398-400.

331 20. Ogushi Y, Eguchi H, Kuwahara T, Hayabuchi N, Kawabata M. Molecular genetic investigations of 332 contaminated contact lens storage cases as reservoirs of Pseudomonas aeruginosa keratitis. Jpn J 333 Ophthalmol 2010;54:550-4.

334 21. Konda N, Motukupally SR, Garg P, Sharma S, Ali MH, Willcox MD. Microbial analyses of contact 335 lens-associated microbial keratitis. Optom Vis Sci 2014;91:47-53.

336 22. Das S, Sheorey H, Taylor HR, Vajpayee RB. Association between cultures of contact lens and 337 corneal scraping in contact lens related microbial keratitis. Arch Ophthalmol 2007;125:1182-5.

338 23. Jiang Y, Jacobs M, Bajaksouzian S, Foster AN, Debanne SM, Bielefeld R, Garvey M, Raghupathy 339 S, Kern J, Szczotka-Flynn LB. Risk factors for microbial bioburden during daily wear of silicone hydrogel 340 contact lenses. Eye Contact Lens 2014;40:148-56.

341 24. Kilvington S, Shovlin J, Nikolic M. Identification and susceptibility to multipurpose disinfectant 342 solutions of bacteria isolated from contact lens storage cases of patients with corneal infiltrative events. 343 Cont Lens Anterior Eye 2013;36:294-8. 
344 25. Wiley L, Bridge DR, Wiley LA, Odom JV, Elliott T, Olson JC. Bacterial biofilm diversity in contact 345 lens-related disease: emerging role of Achromobacter, Stenotrophomonas, and Delftia. Invest Ophthalmol 346 Vis Sci 2012;53:3896-905.

347 26. Wilson LA, Sawant AD, Simmons RB, Ahearn DG. Microbial contamination of contact lens storage 348 cases and solutions. Am J Ophthalmol 1990;110:193-8.

$34927 . \quad$ Devonshire P, Munro FA, Abernethy C, Clark BJ. Microbial contamination of contact lens cases in 350 the west of Scotland. Br J Ophthalmol 1993;77:41-5.

351 28. Gray TB, Cursons RT, Sherwan JF, Rose PR. Acanthamoeba, bacterial, and fungal contamination 352 of contact lens storage cases. Br J Ophthalmol 1995;79:601-5.

353 29. Pens CJ, da Costa M, Fadanelli C, Caumo K, Rott M. Acanthamoeba spp. and bacterial 354 contamination in contact lens storage cases and the relationship to user profiles. Parasitol Res $355 \quad 2008 ; 103: 1241-5$.

356 30. Dantam J, Zhu H, Willcox M, Ozkan J, Naduvilath T, Thomas V, Stapleton F. In vivo assessment 357 of antimicrobial efficacy of silver-impregnated contact lens storage cases. Invest Ophthalmol Vis Sci $358 \quad 2012 ; 53: 1641-8$.

359 31. Simmons PA, Edrington TB, Hsieh L, Wang L. Bacterial contamination rate of soft contact lens 360 cases. International Contact Lens Clinic 1991;18:188-91.

361 32. Midelfart J, Midelfart A, Bevanger L. Microbial contamination of contact lens cases among medical 362 students. CLAO J 1996;22:21-4.

363 33. Kanpolat A, Kalayci D, Arman D, Duruk K. Contamination in contact lens care systems. CLAO J $364 \quad 1992 ; 18: 105-7$.

365 34. Larkin DF, Kilvington S, Easty DL. Contamination of contact lens storage cases by Acanthamoeba 366 and bacteria. Br J Ophthalmol 1990;74:133-5.

367 35. Wu YT, Zhu H, Willcox M, Stapleton F. Removal of biofilm from contact lens storage cases. Invest 368 Ophthalmol Vis Sci 2010;51:6329-33.

369 36. Wu YT, Willcox MD, Stapleton F. The effect of contact lens hygiene behavior on lens case 370 contamination. Optom Vis Sci 2015;92:167-74. 
371 37. Kuzman T, Kutija MB, Juri J, Jandroković S, Škegro I, Olujić SM, Kordić R, Cerovski B. Lens

372 wearers non-compliance-Is there an association with lens case contamination? Contact Lens and Anterior

373 Eye 2014;37:99-105.

374 38. Lakkis C, Anastasopoulos F, Terry C, Borazjani R. Time course of the development of contact lens 375 case and contact lens contamination. Invest Ophthalmol Vis Sci 2009;50:E-abstract 6352.

376 39. Rosenthal RA, Sutton SV, Schlech BA. Review of standard for evaluating the effectiveness of 377 contact lens disinfectants. PDA J Pharm Sci Technol 2002;56:37-50.

378 40. Fleiszig SM, Efron N. Microbial flora in eyes of current and former contact lens wearers. J Clin 379 Microbiol 1992;30:1156-61.

380 41. Rosenthal RA, Stein JM, McAnally CL, Schlech BA. A comparative study of the microbiologic 381 effectiveness of chemical disinfectants and peroxide-neutralizer systems. CLAO J 1995;21:99-110.

382 42. Wilson LA, Sawant AD, Ahearn DG. Comparative efficacies of soft contact lens disinfectant 383 solutions against microbial films in lens cases. Arch Ophthalmol 1991;109:1155-7.

384 43. Szczotka-Flynn LB, Imamura Y, Chandra J, Yu C, Mukherjee PK, Pearlman E, Ghannoum MA. 385 Increased resistance of contact lens-related bacterial biofilms to antimicrobial activity of soft contact lens 386 care solutions. Cornea 2009;28:918-26.

387 44. ISO 14729. Ophthalmic optics-contact lens care products - Microbiological requirements and test 388 methods for products and regimens for hygenic management of contact lenses. In. Geneva, Switzerland: 389 International Organization for Standardization; 2001.

390 45. Guidance for industry: Premarket notification [510(k)]. Guidance document for contact lens care 391 products. Food and Drug Administration; 1997. Available at: 392 http://www.fda.gov/downloads/medicaldevices/deviceregulationandguidance/guidancedocuments/ucm080 393 218.pdf. Accessed February 1, 2016.

394 46. Tilia D, Lazon de la Jara P, Zhu H, Naduvilath TJ, Holden BA. The effect of compliance on contact 395 lens case contamination. Optom Vis Sci 2014;91:262-71.

396 47. Vijay AK, Willcox M, Zhu H, Stapleton F. Contact lens storage case hygiene practice and storage 397 case contamination. Eye Contact Lens 2015;41:91-7. 
398 48. Wu YT, Teng YJ, Nicholas M, Harmis N, Zhu H, Willcox MD, Stapleton F. Impact of lens case 399 hygiene guidelines on contact lens case contamination. Optom Vis Sci 2011;88:E1180-7.

400 49. Wu YT, Zhu H, Willcox M, Stapleton F. The effectiveness of various cleaning regimens and current 401 guidelines in contact lens case biofilm removal. Invest Ophthalmol Vis Sci 2011;52:5287-92.

402 50. Wu YT, Zhu H, Willcox M, Stapleton F. Impact of cleaning regimens in silver-impregnated and 403 hydrogen peroxide lens cases. Eye Contact Lens 2011;37:365-9.

404 51. Wu Y, Carnt N, Willcox M, Stapleton F. Contact lens and lens storage case cleaning instructions: 405 whose advice should we follow? Eye Contact Lens 2010;36:68-72.

406 52. Hickson-Curran S, Chalmers RL, Riley C. Patient attitudes and behavior regarding hygiene and 407 replacement of soft contact lenses and storage cases. Cont Lens Anterior Eye 2011;34:207-15. 


\section{FIGURE 1.}

Microbial contamination of storage cases used with different CL care solutions in this study.

\section{FIGURE 2.}

Levels of microbial contamination in storage cases (mean of Log CFU/ storage case well \pm SD) maintained with different $C L$ care solutions.

\section{FIGURE 3.}

Frequency of bacterial and fungal contamination in storage cases maintained with different care CL solutions. 


\section{TABLE 1.}

Contact lens care solutions used in this study

\begin{tabular}{|c|c|c|c|c|}
\hline & $\begin{array}{l}\text { Biotrue } \\
\text { (North America and UK) }\end{array}$ & $\begin{array}{l}\text { OPTI-FREE PureMoist } \\
\text { (North America and UK) }\end{array}$ & $\begin{array}{l}\text { RevitaLens OcuTec } \\
\text { (North America) } \\
\text { Complete RevitaLens } \\
\text { (UK) }\end{array}$ & $\begin{array}{l}\text { CLEAR CARE (North } \\
\text { America) } \\
\text { AO Sept Plus } \\
\text { (UK) }\end{array}$ \\
\hline Manufacturer & BAUSCH + LOMB & ALCON Inc & Abbott Medical Optics & ALCON Inc \\
\hline $\begin{array}{l}\text { Disinfectant } \\
\text { agent }\end{array}$ & $\begin{array}{l}\text { polyaminopropyl biguanide } \\
0.00013 \% \mathrm{w} / \mathrm{v} \text {, polyquaternium } \\
0.0001 \% \mathrm{w} / \mathrm{v}\end{array}$ & $\begin{array}{l}\text { POLYQUAD (polyquaternium-1) } \\
0.001 \% \text {, ALDOX } \\
\text { (myristamidopropyl } \\
\text { dimethylamine) } 0.0006 \%\end{array}$ & $\begin{array}{l}\text { Polyquaternium-1 } \\
0.0003 \% \text {, Alexidine } \\
0.00016 \%\end{array}$ & $\begin{array}{l}\text { hydrogen peroxide } 3 \% \\
(\mathrm{w} / \mathrm{v}) \text {, sodium chloride } \\
0.79 \%\end{array}$ \\
\hline Buffer & $\begin{array}{l}\text { boric acid, sodium borate, } \\
\text { sodium chloride }\end{array}$ & $\begin{array}{l}\text { boric acid, sorbitol, sodium } \\
\text { chloride }\end{array}$ & $\begin{array}{l}\text { boric acid, sodium borate } \\
\text { decahydrate, trisodium } \\
\text { citrate dehydrate, sodium } \\
\text { chloride }\end{array}$ & $\begin{array}{l}\text { phosphate buffer, } \\
\text { phosphonic acid }\end{array}$ \\
\hline Chelating agent & edetate disodium & disodium EDTA & edetate disodium (EDTA) & \\
\hline Surfactatnt & poloxamine & sodium citrate & Tetronic 904 & Pluronic 17R4 \\
\hline $\begin{array}{l}\text { Conditioning/ } \\
\text { Wetting agent }\end{array}$ & hyaluronan & $\begin{array}{l}\text { TETRONIC } 1304 \text { and HydraGlyde } \\
\text { Moisture Matrix [EOBO-41- } \\
\text { polyoxyethylene-polyoxybutylene] }\end{array}$ & & \\
\hline Others & sulfobetaine & aminomethyl propanol & purified water & \\
\hline
\end{tabular}




\section{TABLE 2.}

Frequency of microbial contamination in $\mathrm{CL}$ storage cases with the use of different care solutions, for a given CL material (each subject used one CL material and all four CL care solutions in random order)

\begin{tabular}{|c|c|c|c|c|c|c|}
\hline \multirow{3}{*}{ Care solution } & \multicolumn{6}{|c|}{ CL material } \\
\hline & \multicolumn{2}{|c|}{ etafilcon $A(n=13)$} & \multicolumn{2}{|c|}{ galyfilcon $A(n=12)$} & \multicolumn{2}{|c|}{ senofilcon $A(n=13)$} \\
\hline & Yes* (\%) & No $^{\#}(\%)$ & Yes* $(\%)$ & No $^{\#}(\%)$ & Yes* $\left.^{*} \%\right)$ & No $^{\#}(\%)$ \\
\hline Biotrue & 79 & 21 & 83 & 17 & 85 & 15 \\
\hline OPTI-FREE PureMoist & 100 & 0 & 100 & 0 & 93 & 7 \\
\hline RevitaLens OcuTec & 69 & 31 & 92 & 8 & 81 & 19 \\
\hline CLEAR CARE & 85 & 15 & 92 & 8 & 100 & 0 \\
\hline
\end{tabular}

"contaminated storage cases; " uncontaminated storage cases 
TABLE 3.

Comparison of levels of Gram-positive bacteria recovered from different storage cases

\begin{tabular}{llllll}
\hline & & \multicolumn{3}{c}{$p$ values for pairwise comparisons using Bonferroni } \\
correction
\end{tabular}




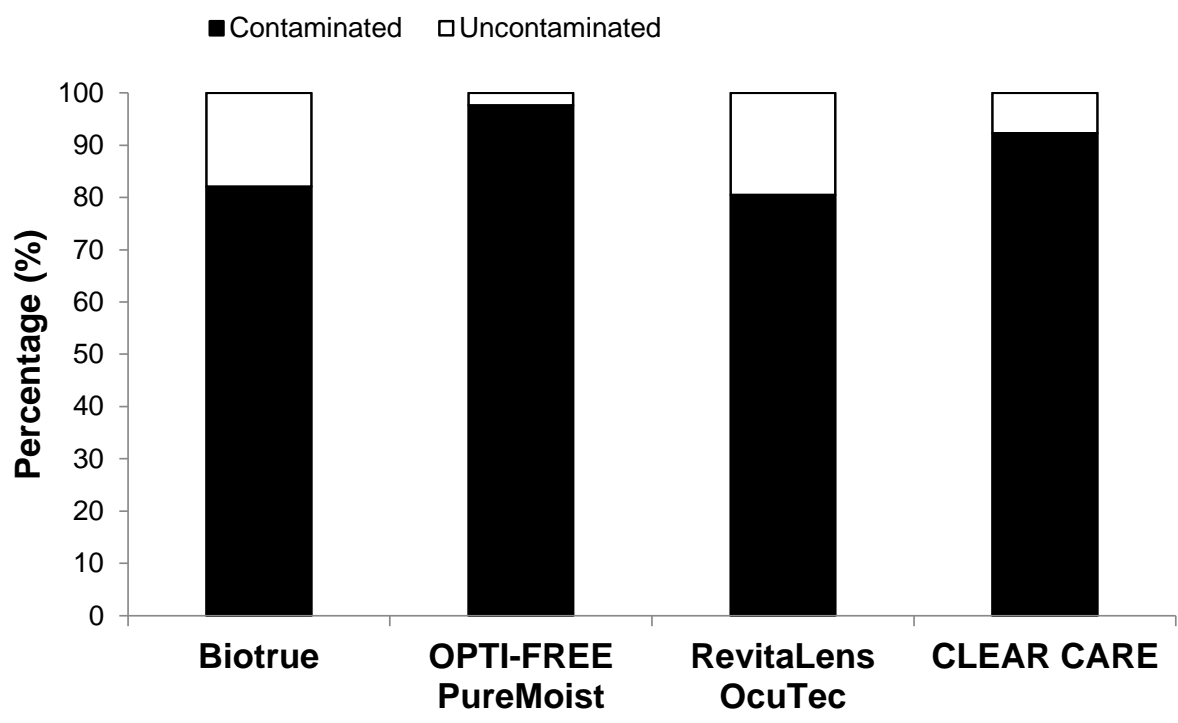


-Gram-postive bacteria पGram-negative bacteria 口Fungi

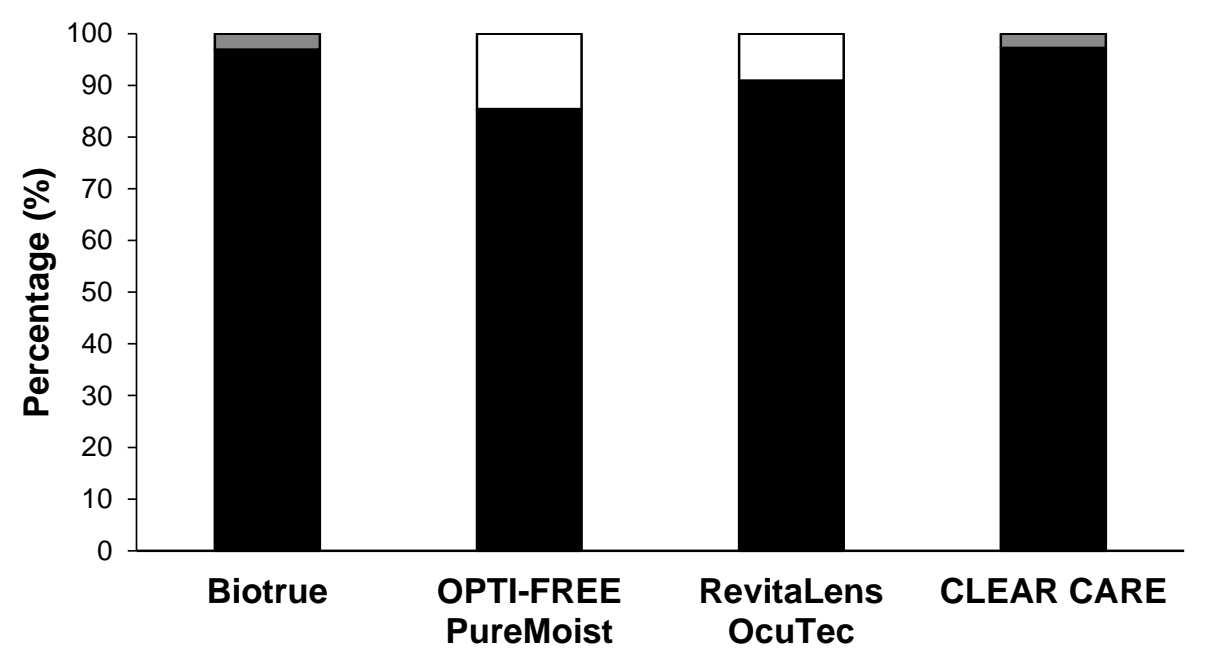




\title{
(0). Wolters Kluwer Lippincott Health \\ Williams \& Wilkins
}

\author{
LICENSING AGREEMENT \\ Optometry and Vision Science / American Academy of Optometry \\ Lippincott williams $\&$ Wilkins, a business of Wolters kluwer Health
}

This Agreement is made by and between Lippincott Williams 8 wilkins, a business of Wolters Kluwer Health, Inc. a corporation organized under the laws of the State of New York and having as one of its principal offices a location at Two Commerce Square 2001 Market Street Philadelphia, PA 19103 USA (referred to in this Agreement as "The Publisher") and Jaya Dantam (insert name - referred to in this agreement as "The Copyright Owner").

For the Content:

ovs Announces image file name, as submitted to the Editorial office The unhappy swab

Content to appear in:

OVS manuscript number/corresponding author's surname OVS15496R1/Dantam

\section{LICENSE TERMS}

The Copyright Owner hereby grants Iippincott Williams \& Wilkins and the American Academy of Optometry a non-exclusive license to publish the Content, to copy the Content, for commercial and non-commercial use, to issue copies of the Content, to the public and to communicate the Content, to the public, in electronic form, in all languages. For the purposes of this Agreement, the Content, is considered to include the image(s) submitted for publication.

The Copyright Owner grants Lippincott Williams \& Wilkins the right to reproduce content in the journal publication optometry and Vision science. 
SIGNED AND DATED:

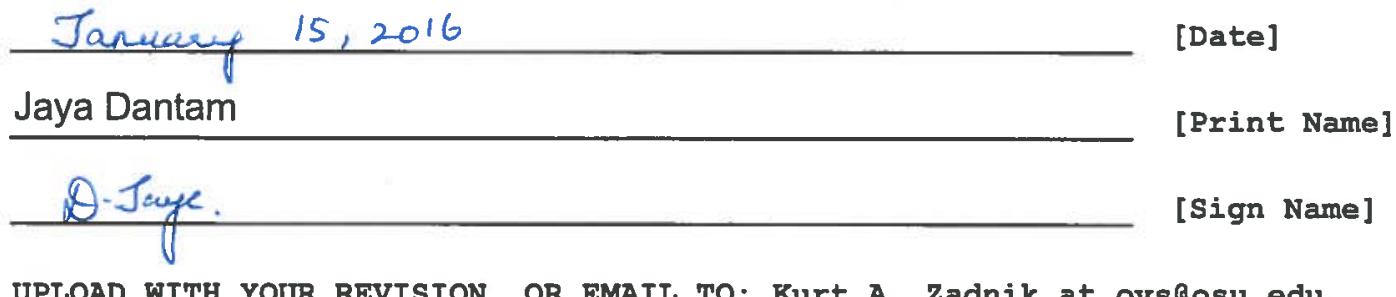

UPLOAD WITH YOUR REVISION, OR EMAIL TO: Kurt A. Zadnik at ovseosu.edu. 